\title{
Community acceptance challenges of renewable energy transition: A tale of two solar parks in Limpopo, South Africa
}

\section{Elvis Modikela Nkoana}

Department of Adult Basic Education and Youth Development, School of Educational Studies, College of Education, P O Box 392, University of South Africa, 0003; Institute of Environment and Sustainable Development, University of Antwerp, Universiteitsplein 1, 2610 Antwerp, Belgium; International Institute for Applied Systems Analysis, Schlossplatz 1 - A-2361 Laxenburg, Austria

\begin{abstract}
Severe problems of climate change, inequality, poverty, and unemployment have compelled the South African government to pass legislation that introduced programmes aimed at achieving energy security, promoting economic development, and realising environmental protection. The Renewable Energy Independent Power Producers Procurement Programme objective is to increase the share of renewable sources in the national energy mix, deliver jobs and economic empowerment for black communities (Africans, Coloureds, and Indians) and cut harmful greenhouse gas emissions. Independent power producers (IPPs) must demonstrate that their projects contribute to job creation and broad-based black economic empowerment during the bidding process. To date, studies suggest that IPPs are missing this government target. This study investigated this phenomenon through face-to-face interviews with key informants involved in the IPP process at two solar parks in Limpopo province. Qualitative content analysis was used to analyse and interpret the field notes. Findings reveal that the process of involving local communities in the governance of
\end{abstract}

the IPP process is highly fragmented, leaving room for powerful stakeholders to thrive over vulnerable community members. The lack of monitoring by the government IPP office enables a prominent not-forprofit organisation to abscond from its responsibility of setting up a community trust for the benefit of local residents. Also, limited skills in the local communities mean that young people are employed in low-paying construction jobs that end after project commissioning. Lack of awareness and knowledge about IPP commitments made during the bidding process are responsible for the 'wait and see' approach of local leaders and community members. In the short-term, awareness and capacity-building interventions for local leaders and community members are urgently required to conscientise beneficiaries. It is imperative to create a participatory governance framework that prioritises vulnerable stakeholders as a long-term solution.

Keywords: challenges, social acceptance, IPP, Limpopo Province, REIPPPP, solar parks

Journal of Energy in Southern Africa 29(1): 34-40

DOI: http://dx.doi.org/10.17159/2413-3051/2018/v29i1a2540

Published by the Energy Research Centre, University of Cape Town ISSN: 2413-3051 http://journals.assaf.org.za/jesa

Sponsored by the Department of Science and Technology

\footnotetext{
* Corresponding author: Tel: +27 12 4812767;

+27 60 6253201; Email: nkoana.elvis6@gmail.com;

nkoanem@unisa.ac.za
} 


\section{Introduction}

South Africa's energy sector must contribute to redressing severe problems of inequality, poverty and unemployment, while transitioning from polluting fossil fuels to clean renewable energy sources. South Africa is among the twenty top global emitters of harmful greenhouse gases because of its high dependence on coal as a primary energy source (Department of Energy, 2009). The country has domestic and international obligations to promote economic development, achieve energy security, and realise environmental protection. To achieve this, growth outcomes in the National Development Plan (NDP) for horizon 2030 have a strong link with the Renewable Energy Independent Power Producers Procurement Programme (REIPPPP) (IPP office, 2016). The REIPPPP process is an ambitious government plan to introduce renewable energy into the national energy mix and deliver on local content requirements for South Africans, particularly those in rural areas, where most of the projects are located.

In this context, local content requirements means 'local community empowerment targets', which refer to specific community-based initiatives that directly benefit the community instead of 'economic development' that may include domestic industrialisation and preferential procurement. Local community empowerment targets may include enterprise development, management control, job creation and local ownership (Eberhard et al., 2014; Wlokas et al., 2012; Pegels, 2010). Studies have shown, however, that renewable energy developers, or independent power producers (IPPs), do not deliver on the local community empowerment targets set during the bidding process (Wlokas et al., 2017; Eberhard et al., 2014; Wlokas et al., 2012; Pegels, 2010). This study confirms this phenomenon by unpacking intricate details of the community challenges experienced during the planning, construction, and management of two solar energy parks in Limpopo Province of South Africa. The next section examines South Africa's renewable energy transition, with an overview of the REIPPPP process. Then follows a formulation of the problem examined and details of the study area and research methodology. Section 5 looks at conceptualising community acceptance in renewable energy transition. Section 6 discusses findings and key challenges, and Section 7 presents conclusion.

\section{South Africa's renewable energy transition: Overview of the REIPPPP process}

The Bill of Rights in the Constitution of the Republic of South Africa recognises that promoting economic development, attaining energy security and achieving environment sustainability will require investment in renewable energy (Constitution, 1996).
The Constitution has set a firm foundation for succeeding laws and strategies, including the White Paper on Energy Policy (1998), Renewable Energy White Paper (2003), the National Climate Change Response Policy White Paper (2011), and the Integrated Resources Plan (IRP) (2010) that ushered in the transition to renewable energy in South Africa.

It is through these laws and strategies that the NDP requires the development of $10000 \mathrm{MW}$ additional electricity capacity to be established by 2025 against the 2013 baseline of $44000 \mathrm{MW}$. The policy adjusted IRP 2010 then developed the preferred energy mix with which to meet the electricity needs over a 20-year planning horizon to 2030. In line with the national commitment to transition to a lowcarbon economy, $17800 \mathrm{MW}$ of the 2030 target are expected to be from renewable energy sources, with $5000 \mathrm{MW}$ to be delivered online by 2019 and further $2000 \mathrm{MW}$ (i.e. combined $7500 \mathrm{MW}$ ) online by 2020. These renewable energy sources would come from onshore wind, concentrated solar power, solar photovoltaic, biomass, biogas, landfill gas and small hydro (Mandela Institute \& Konrad Adenauer Stiftung, 2014). Small hydropower technology deployment is considered despite South Africa's current drought crisis that has occasioned severe water shortages, most notably in the Western Cape.

The government realises renewable energy within its national energy mix through the REIPPPP, which invites request for proposals from potential IPPs through a public tendering process. The Preferential Procurement Policy Framework Act 05 of 2000 and the Broad-Based Black Economic Empowerment Act 53 of 2003 recommend that IPPs be awarded tenders to develop renewable energy based on 70/30 allocation of points to price factors and non-price factors (economic development) respectively. The Department of Energy (DoE) insists that renewable energy developers identify the socio-economic needs of communities within a 50 kilometre radius of the area in which an IPP operates. Although there is clarity in terms of the price factor, which accounts for $70 \%$ during bid evaluation, the confusion regarding the economic development factors, which accounts for $30 \%$ during bid evaluation, persists. The confusion stems from the lack of guidance on how surrounding communities' empowerment targets should be prepared and evaluated, the incorporation of local stakeholders' concerns, and short timeframes to prepare proposals between the bidding periods (windows 1, 2, and 3) (Wlokas et al., 2012).

The DoE appointed 'Economic Development [Independent] Monitors' to monitor and evaluate IPPs reporting and to confirm their compliance with economic development objectives. Economic development objectives are designed to incentivise bidders to promote job creation, local content, own- 
ership, management control, preferential procurement, enterprise development, and socio-economic development (IPP office, 2007).

This $30 \%$ apportionment of economic development factors in the bid evaluation process is used as a vehicle to include black (Africans, Indians, and Coloureds) stakeholders during the REIPPPP process and beyond. These stakeholders are mainly emerging black entrepreneurs and communities within the arbitrary 50 kilometre radius of the renewable energy site. It is highly unlikely that black emerging entrepreneurs can compete with multinational corporations that are bidding for renewable energy projects on the price factor that accounts for $70 \%$ of the bid evaluation (Wlokas et al. 2012). Instead, the $30 \%$ apportionment of economic development factors becomes a vehicle to support emerging black entrepreneurs in the renewable energy sector. Part of the $30 \%$ apportionment is on local community empowerment targets that are intended to benefit surrounding communities. During the bidding process, IPPs are expected to submit a plan detailing how they will deliver the local community empowerment targets during the operation of their renewable energy project. Targets include job creation for locals, promoting local content, supporting local businesses and communitybased organisations, as well as setting up a community trust that will disbursed around $1 \%$ of IPP profits to surrounding communities (IPP office, 2016; 2017). To comply with this, IPPs meet with sur- rounding communities and conduct a community needs analysis, and the final report forms part of their bidding documents.

\section{Problem statement}

The IPPs make economic and local community empowerment commitments as part of the REIPPPP bidding process. Once the successful company is awarded the contracts, the DoE expects the IPP to implement the commitments made during the bidding process. This is when the challenges in the implementation of these economic and local community empowerment commitments emerge. These challenges relate to the participation of various stakeholders, particularly surrounding community members, in the renewable energy infrastructure development and management processes, a problem the current study investigated.

\section{Study area and research methodology}

Witkop solar park is located 21.9 kilometres south of Polokwane (the capital of Limpopo) on the Wildebeestfontein farm situated on a privately owned land, while the Soutpan solar park is located 108.0 kilometres north of Polokwane on the Zuurbult farm (land tenure information not available). Both are privately owned and operated by IPPs and utilise photovoltaic technology to generate a combined daily output of 58 megawatts of electricity, which is fed into the national energy grid through nearby substations.

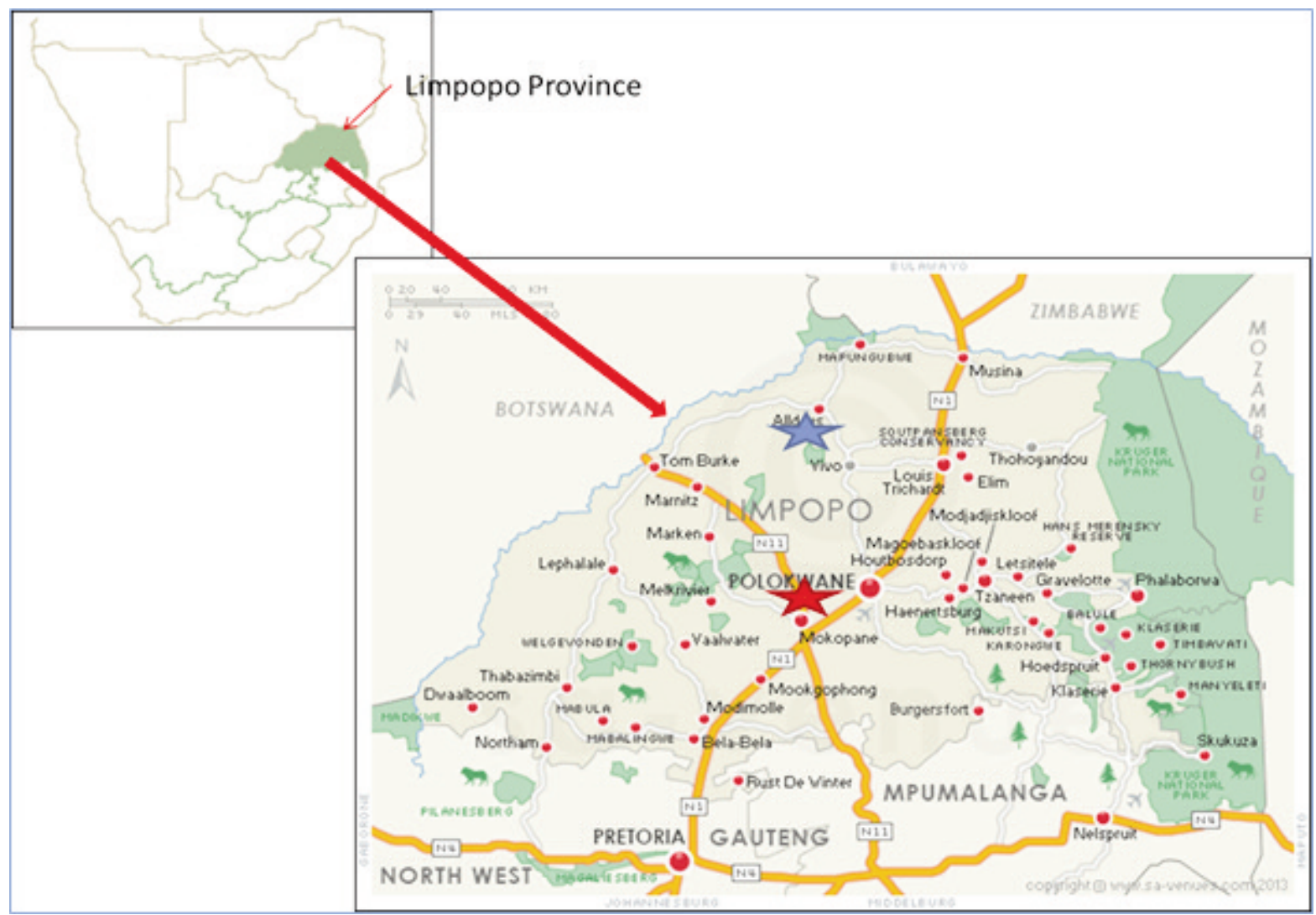

Figure 1: The locations of Witkop (red star) and Soutpan (blue star) solar parks in Limpopo. 
Interviews were administered through face-toface sessions with seven key informants from the private companies (owners and operators of solar parks), the traditional leaders, and authorities from the local government department responsible for local economic development. Primary data emanating from these interviews was analysed through content and thematic analysis techniques (Vaismoradi et al., 2013).

\section{Conceptualising community acceptance in renewable energy transition}

According to Wüstenhagen et al. (2007), there are three dimensions of social acceptance: socio-political, community, and market (see Figure 2). Sociopolitical acceptance is a broad term that encompasses the acceptance of renewable energy deployment by varying actors such as local authorities and energy companies (Eskom, in this case) and sectors including governments of any society. Market acceptance refers to the willingness to pay for renewable energy by consumers and a desire to finance such technologies by local and foreign investors. Financial participation of consumers as investors in renewable energy projects has been realised in Germany (Yildiz, 2014) and Japan (Maruyama et al., 2007). Community acceptance refers in this case to consensus on the planning, construction and management of renewable energy project by members of the community located within 50 kilometre of the site (IPP office, 2016).

Public acceptance (Cohen et al., 2014), social acceptance (Wustenhagen et al., 2007), local acceptance (Nadai, 2007), or community acceptance of renewable energy technologies was largely neglected in the 1980s because of the high levels of support from communities -particularly with reference to wind energy. There is, however, evidence of public resistance to, and concerns about, the implementation of renewable energy technologies near residential communities in various countries, including Australia (Yiridoe, 2014), China (Liu et al., 2013), Colombia (Rosso-Ceron \& Kafarov, 2015), Germany (Musall \& Kuik, 2011), Japan (Maruyama et al., 2007), Netherlands (Van OS et al., 2014), United Kingdom (Lock et al., 2014, Scotland
(Shamsuzzoha et al., 2012), as well as South Africa (Pegels, 2010). Public resistance to energy technologies is not a new phenomenon and it can be traced back to the contested siting of decisions of nuclear power plants, nuclear waste storage facilities, or large hydropower dams (Wustenhagen et al., 2007). Civil society organisations notably Treasure Karoo Action Group's public protests have played a role in compelling the South African government to place a temporary moratorium on shale gas exploration in the pristine Karoo region of the Northern Cape. Local opposition to large-scale renewable energy deployment is mainly driven by factors including the environmental (noise and visual pollution), cultural (ancestral burial land), financial (investors, willingness to pay), and socio-political factors (job creation, mistrust, social injustice) (Wusten- hagen et al., 2007; De Araujo, \& De Freitas, 2008). Studies have also pointed to the fact that in certain cases these concerns have been addressed by, for example, designing wind turbines that minimise noise; recognising the aesthetics and tourism potential of wind turbine sites; contributing to an increase in quality of life through increased income of local population; availability of electricity and upgrading of infrastructure (De Araujo, \& De Freitas, 2008; Yazdanpanah et al., 2015). The socio-political factors of community acceptance such as job creation, mistrust of renewable energy developers, and social injustice feature prominently in section 6.

\section{Findings and discussion of key challenges in the renewable energy transition at the community level \\ Social (in)justice and environmental degradation}

In Witkop solar park, traditional leaders were concerned that electricity was both unaffordable and unreliable (due to Eskom's planned power outages) and this compelled the residents to harvest the nearby ecosystem for firewood, leading to environmental degradation. Public concern around high electricity prices is not unique to South Africa, but has been stated in, for example, Australia (Yiridoe, 2014) and Greece (Zografakis et al., 2010), partic-

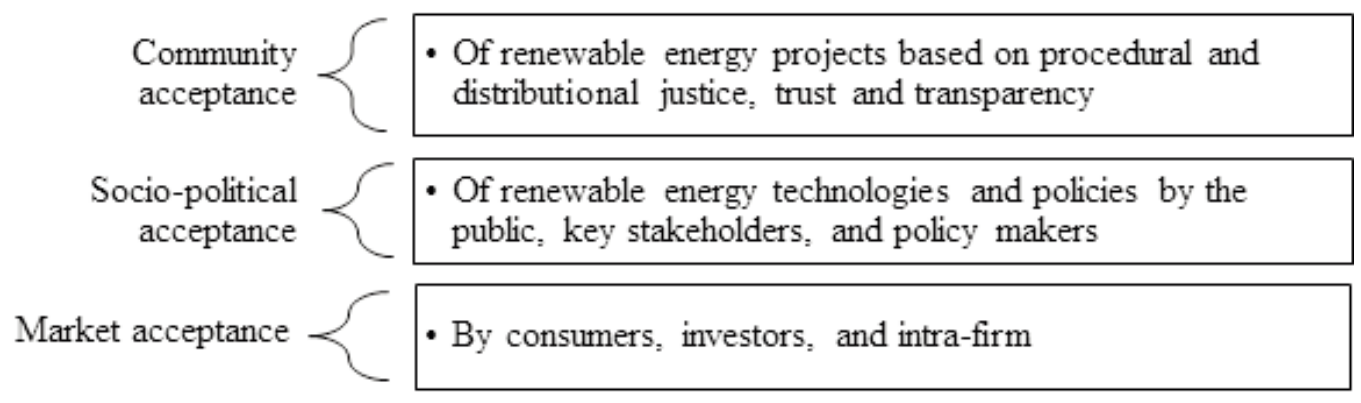

Figure 2: Social acceptance of renewable energy deployment (adapted from Wüstenhagen et al., 2007). 
ularly on electricity generated from renewable energy sources. This unwillingness to pay is driven by socio-political (i.e. inclusive participation) and demographic (i.e. occupation) factors (Scarpa \& Willis, 2010; Zografakis et al., 2010). The local leaders at the solar parks were also concerned that electricity is generated within their local communities but inaccessible to their residents - implying issues of inequity in access to locally generated resources.

\section{Insecure land tenure}

The community liaison officers at the Witkop and Soutpan solar parks indicated that private citizens own the land of which the two renewable energy projects were built. Land ownership provides pathways through which community members can participate in the renewable energy projects, more so if community members jointly own the land on which the renewable energy facility is constructed. Various types of land ownership do, however, exist in remote rural areas. Land rights in rural areas are mostly held by either traditional leaders, the local municipality, or commercial farmers (Ntsebeza, 2004). These forms of land tenure do not offer the local community members any opportunity to participate in the renewable energy project through ownership of land. Secure land tenure can offer local communities pathways to participate in renewable energy projects, thereby increasing community acceptance.

\section{Stakeholder awareness, identification, and management}

Low levels of awareness among residents regarding local community empowerment targets agreed to by renewable energy companies lead community members and local leaders to adopt a 'wait and see' approach, as in the cases of Witkop and Soutpan solar parks. In turn, this allowed the renewable energy companies to dictate local community empowerment targets to the residents within the stipulated 50 kilometre radius. Furthermore, community acceptance challenges start at the planning phase with the problematic issue of identifying communities within the radius. This challenge is further compounded by the complicated process of stakeholder identification and management (Wlokas et al., 2012). Various stakeholders play different roles at varying phases of the renewable energy project lifecycle. These community stakeholders might include ordinary community residents, communitybased organisations (i.e. schools, churches, selfhelp groups and community enterprises), not-forprofit organisations, and traditional authorities. Once the stakeholders are identified, the question of how they will benefit during and after the project implementation life cycle arises. Answering these questions through a communication process will enable community stakeholders to gauge their involvement and manage their expectations. This is important, since significant profits from renewable energy sites are sometime realised only a few years after the commissioning of such projects (Pegels, 2010). Neglecting this process can perpetuate a 'tyranny of participation' (Cooke \& Kothari, 2001), which reinforces the control of powerful stakeholders over vulnerable communities, as was the case in both solar parks.

\section{Unskilled labour and management control}

The key informants indicated that the construction phase of the solar parks created short-term jobs for local people in the surrounding areas. The contractor appointed by the IPP to construct the Witkop solar park agreed to employ local people during the construction phase, but flouted this agreement and sourced day labourers from the nearby city instead of the local villages. Although this is legal, it sparked a violent community protest that delayed the construction of the solar park. A local steering committee composed of traditional and elected leaders was formed to quell the protest by facilitating the hiring of local residents. In the other case study area, the local residents' employment on the solar park construction phase was facilitated by the local municipality. In both cases, local residents had to provide identity documents and proof of residence as evidence that they resided in the nearby communities.

Both skilled and unskilled labour is required during the construction and management of a renewable energy project. Renewable energy projects are mostly located in remote rural areas with unskilled labour. This unskilled labour can only participate during the construction phase as manual labourers on site and thereafter become redundant, being laid off during more complicated operations and maintenance of the facility. This form of job creation is unsustainable. The challenges of unskilled personnel are not limited to 'unsustainable' job creation but can extend to revenue management that links directly with the management of stakeholder expectations.

\section{Socio-economic development (ownership through community trusts)}

The IPPs that developed and operate the two solar parks in this study appointed a prominent not-forprofit organisation to set-up community trusts in both communities. The present study, however, found that the appointed organisation has not setup the community trusts, therefore making contact with the community difficult. The community liaison officers for the two solar parks complained about being overworked because they had to fill in the gap left by the not-for-profit organisation. The community liaison officers had to distribute material incentives to community-based organisations to 
appease the local residents. The IPPs are expected to set aside up to $2.5 \%$ of their annual profits to support enterprise and socio-economic development in the local communities (IPP office, 2016). The IPPs set up community (development) trusts to manage these revenues (approximately R29.2 billion net income over 20 years) once they become available from the year 2028 (IPP office, 2016; Eberhard et al., 2014; Wlokas et al., 2012). The presence of semi-literate and unskilled community members might, however, leave room for dominant stakeholders (including not-for-profit organisations, local chiefs, the educated elite and political leaders) to abuse their status as community trust board members once they are established.

\section{Local content requirements, preferential procurement, and enterprise development}

The key informants complained that raw material (concrete and sand), cleaning material and tools were sourced from multinational and national private companies based in the large city, ignoring the community-based enterprises. The IPPs did, however, support community-based organisations through the sterling work of the two community liaison officers. However, in terms of local economic development, the REIPPPP process requires that IPPs acquire services such as raw materials and technology from local suppliers. The government hoped that this would boost local black entrepreneurs and also develop the local renewable energy manufacturing industry. In reality, the IPPs sourced raw materials from established local companies owned by white South Africans. It is worth noting that these IPPs still complied with the local content requirement because they sourced their raw materials within South Africa, albeit from a historically advantaged racial group. To enable genuine participation of black people, the government should answer these questions: How local is local? Who should IPPs buy from? The first question addresses the fact that IPPs might source materials from established suppliers (who are generally white South Africans) and ignore the emerging black suppliers, yet without violating the terms of their contract with the government. The second question fits directly with the first one and implies that the government should monitor whether IPPs are sourcing services from emerging black entrepreneurs. The South African renewable energy technology manufacturing industry is still in its infancy and IPPs prefer buying from the Far East and Europe, which has excluded the local entrepreneurs from participating in the REIPPPP process.

\section{Conclusions}

The important lesson drawn from the present study is that the starting point towards realising community acceptance is the inclusion of diverse stakehold- ers in the renewable energy project planning, development, and management. The participation of surrounding communities in the governance of renewable energy projects might lead to community acceptance and avoidance of construction delays. This study also revealed that challenges are not limited to community acceptance of renewable energy technologies, but also extend to the DoE's task of monitoring and evaluating the implementation of economic and local community empowerment commitments made to surrounding communities during the bidding process.

\section{Acknowledgements}

The following groups and organisations are acknowledged: traditional leaders; elected leaders; government officials; community liaison officers involved in the solar parks. The University of the Witwatersrand, and Konrad Adeneur Stiftung provided financial support.

\section{References}

Cohen, J. J., Reichl, J., and Schmidthaler, M. 2014. Refocussing research efforts on the public acceptance of energy infrastructure: A critical review. Energy 76: 4-9. https://doi.org/10.1016/j.energy.2013.12.056.

Cooke, B., \& Kothari, U. (Eds.). 2001. Participation: The new tyranny? Zed Books.

De Araújo, M. S. M., and de Freitas, M. A. V. 2008. Acceptance of renewable energy innovation in Brazil - Case study of wind energy. Renewable and Sustainable Energy Reviews 12(2): 584-591. https://doi.org/10.1016/j.rser.2006.03.017.

Department of Environment. 2011. National climate change response policy white paper. Pretoria: Government Printer.

Department of Energy. 2009. Digest of South African energy statistics. Pretoria: Government Printer.

Department of Energy. 1998. White paper on the energy policy of the Republic of South Africa. Pretoria: Government Printer.

Department of Minerals and Energy. 2003. Republic of South Africa white paper on renewable energy. Pretoria: Government Printer.

Devine-Wright, P. 2007. Reconsidering public attitudes and public acceptance of renewable energy technologies: A critical review. (Working Paper No. 1.4). Manchester Architecture Research Centre, University of Manchester. Available online at: http://geography.exeter.ac.uk/beyond_nimbyism/deliverables/bn_ wp1_4.pdf (Accessed 12 July 2017).

Eberhard, A., Leigland, J., and Kolker, J. 2014. South Africa's Renewable Energy IPP Procurement Program. World Bank Publications. Available online at: http://www.gsb.uct.ac.za/files/ppiafreport.pdf (Accessed 12 July 2017).

Evans, B., Parks, J., and Theobald, K. 2011. Urban wind power and the private sector: community benefits, social acceptance and public engagement. Journal of environmental planning and management 54(2): 227-244. https://doi.org/10.1080/09640568.2010.505829. 
IPP Office. 2017. Independent Power Producers Procurement Programme (IPPPP): An overview as at 31 March 2017. Available online at: https://www.ipp-projects.co.za/Publications (Accessed 12 July 2017).

IPP Office. 2016. Independent Power Producers Procurement Programme (IPPPP): An overview as at 30 September 2016. Available online at: https://www.ipp-projects.co.za/Home/Publications. (Accessed 12 July 2017).

Liu, W., Wang, C. and Mol, A. P. 2013. Rural public acceptance of renewable energy deployment: The case of Shandong in China. Applied Energy 102: 1187-1196. https://doi.org/10.1016/j.apenergy.2012.06.057.

Lock, S. J., Smallman, M., Lee, M. and Rydin, Y. 2014. 'Nuclear energy sounded wonderful 40 years ago': UK citizen views on CCS. Energy Policy 66: 428435.

Mandela Institute (MI) and Konrad Adenauer Stiftung (KAS) Foundation. 2014. Report of the scoping workshop on climate change, energy law and the environment, November 2014, Johannesburg, South Africa.

Maruyama, Y., Nishikido, M. and Iida, T. 2007. The rise of community wind power in Japan: Enhanced acceptance through social innovation. Energy Policy 35: 2761-2769. https://doi.org/10.1016/j.enpol.2006.12.010.

Nadai, A. 2007. 'Planning', 'sitting' and the local acceptance of wind power: Some lessons from the French case. Energy Policy 35: 2715-2726. https://doi.org/10.1016/j.enpol.2006.12.003.

Ntsebeza, L. 2004. Democratic decentralisation and traditional authority: Dilemmas of land administration in rural South Africa. The European Journal of Development Research 16(1): 71-89.

Pegels, A. 2010. Renewable energy in South Africa: Potentials, barriers and options for support. Energy policy 38(9): 4945-4954. https://doi.org/10.1016/j.enpol.2010.03.077.

Rosso-Cerón, A. and Kafarov, V. 2015. Barriers to social acceptance of renewable energy systems in Colombia. Current Opinions in Chemical Engineering 10: 103-110. https://doi.org/10.1016/j.coche.2015.08.003.

Scarpa, R. and Willis, K. 2010. Willingness-to-pay for renewable energy: Primary and discretionary choice of British households' for micro-generation technologies. Energy Economics 32(1): 129-136. https://doi.org/10.1016/j.eneco.2009.06.004.

Shamsuzzoha, AHM., Grant, A. and Clarke, J. 2012. Implementation of renewable energy in Scottish rural area: A social study. Renewable and Sustainable Energy Reviews 16: 185-191. https://doi.org/10.1016/j.rser.2011.07.146.

Strazzera, E., Mura, M., and Contu, D. 2012. Combining choice experiments with psychometric scales to assess the social acceptability of wind energy projects: A latent class approach. Energy Policy 48: 334-347.

https://doi.org/10.1016/j.enpol.2012.05.037.

Vaismoradi, M., Turunen, H. and Bondas, T. 2013.
Content analysis and thematic analysis: Implications for conducting a qualitative descriptive study. Nursing and health sciences 15 (3): 398-405.

Van Os, H. W., Herber, R. and Scholtens, B. 2014. Not Under Our Back Yards? A case study of social acceptance of the Northern Netherlands CCS initiative. Renewable and Sustainable Energy Reviews, 30, 923-942. https://doi.org/10.1016/j.rser.2013.11.037.

Wlokas, H. L., Westoby, P. and Soal, S. 2017. Learning from the literature on community development for the implementation of community renewables in South Africa. Journal of Energy in Southern Africa 28(1): 35-44. https://doi.org/10.1016/j.rser.2013.11.037.

Wlokas, H.L., Boyd, A. and Andolfi, M., 2012. Challenges for local community development in private sector-led renewable energy projects in South Africa: An evolving approach. Journal of Energy in Southern Africa 23(4): 46-52.

Wustenhagen, R., Wolsink, M. and Burer, M. J. 2007. Social acceptance of renewable energy innovation: An introduction to the concept. Energy Policy 35: 2683-2691. https://doi.org/10.1016/j.enpol.2006.12.001.

Yazdanpanah, M., Komendantova, N., and Ardestani, R. S. 2015. Governance of energy transition in Iran: Investigating public acceptance and willingness to use renewable energy sources through socio-psychological model. Renewable and Sustainable Energy Reviews 45: 566-673. https://doi.org/10.1016/j.rser.2015.02.002.

Yildiz, Ö. 2014. Financing renewable energy infrastructures via financial citizen participation-The case of Germany. Renewable Energy 68: 677-685. https://doi.org/10.1016/j.renene.2014.02.038

Yiridoe, E. K. 2014. Social acceptance of wind energy development and planning in rural communities of Australia: A consumer analysis. Energy Policy 74: 262-270. https://doi.org/10.1016/j.enpol.2014.08.035.

Zografakis, N., Sifaki, E., Pagalou, M., Nikitaki, G., Psarakis, V. and Tsagarakis, K. P. 2010. Assessment of public acceptance and willingness to pay for renewable energy sources in Crete. Renewable and Sustainable Energy Reviews 14(3): 1088-1095. https://doi.org/10.1016/j.rser.2009.11.009. 